\title{
Glycans as Biomarkers in Prostate Cancer
}

\author{
Emma Scott and Jennifer Munkley *(D) \\ Institute of Genetic Medicine, Newcastle University, Newcastle upon Tyne NE1 3BZ, UK; \\ Emma.Scott@newcastle.ac.uk \\ * Correspondence: Jennifer.munkley@ncl.ac.uk
}

Received: 21 February 2019; Accepted: 17 March 2019; Published: 19 March 2019

\begin{abstract}
Prostate cancer is the most commonly diagnosed malignancy in men, claiming over 350,000 lives worldwide annually. Current diagnosis relies on prostate-specific antigen (PSA) testing, but this misses some aggressive tumours, and leads to the overtreatment of non-harmful disease. Hence, there is an urgent unmet clinical need to identify new diagnostic and prognostic biomarkers. As prostate cancer is a heterogeneous and multifocal disease, it is likely that multiple biomarkers will be needed to guide clinical decisions. Fluid-based biomarkers would be ideal, and attention is now turning to minimally invasive liquid biopsies, which enable the analysis of tumour components in patient blood or urine. Effective diagnostics using liquid biopsies will require a multifaceted approach, and a recent high-profile review discussed combining multiple analytes, including changes to the tumour transcriptome, epigenome, proteome, and metabolome. However, the concentration on genomics-based paramaters for analysing liquid biopsies is potentially missing a goldmine. Glycans have shown huge promise as disease biomarkers, and data suggests that integrating biomarkers across multi-omic platforms (including changes to the glycome) can improve the stratification of patients with prostate cancer. A wide range of alterations to glycans have been observed in prostate cancer, including changes to PSA glycosylation, increased sialylation and core fucosylation, increased O-GlcNacylation, the emergence of cryptic and branched N-glyans, and changes to galectins and proteoglycans. In this review, we discuss the huge potential to exploit glycans as diagnostic and prognostic biomarkers for prostate cancer, and argue that the inclusion of glycans in a multi-analyte liquid biopsy test for prostate cancer will help maximise clinical utility.
\end{abstract}

Keywords: prostate cancer; biomarkers; liquid biopsy; glycans; glycosylation

\section{Introduction}

Prostate cancer is the most common cancer in men, and is a major clinical burden [1]. In the last decade, research into prostate cancer has advanced rapidly, and large advances have been made in both finding new treatments and understanding the underlying biology. However, several areas of urgent unmet clinical need remain, including the identification of: (i) validated biomarkers to complement prostate-specific antigen (PSA) for screening; (ii) prognostic biomarkers with the clinical utility to distinguish indolent and aggressive disease; (iii) molecular stratification methods and predictive biomarkers; and (iv) surrogate end point biomarkers that are valid measures of therapeutic response and survival [2]. As prostate cancer is a heterogeneous and multifocal disease, it is likely that multiple biomarkers will be needed to guide clinical decisions. Fluid-based biomarkers would be ideal, and attention is now turning to minimally invasive liquid biopsies, which enable the analysis of tumour components in patient biological fluids such as blood and urine. Urine is an amenable bodily fluid for prostate cancer biomarker discovery. It is easily obtained in a non-invasive way, and due to the proximity of the prostate to the bladder, urine may carry markers that reflect the development and progression of prostate cancer [3]. Proximal fluids of the prostate such as expressed prostatic secretions 
(fluid secreted by the prostate after a digital rectal prostate massage) can also be collected in urine and used as a source of biomarkers [4]. Whereas traditional tissue biopsies only provide limited snapshots of the tumour and might fail to reflect heterogeneity, liquid biopsies can provide a comprehensive view of all cancerous lesions (primary and metastases) as well as offering the opportunity to track tumour evolution [5].

A 2018 high-profile review in Nature Genetics highlighted that effective diagnostics using liquid biopsies will require the multiparametric analysis of several analytes (including changes to the transcriptome, epigenome, proteome, and the metabolome) within the same blood or urine sample [6]. The detection of changes to the glycome, and more specifically cancer-associated glycan sugar groups, was not included in this review. Glycans have shown huge promise as diagnostic biomarkers for cancer [7-9], and recent data suggests that integrating biomarkers across multi-omic platforms (which includes changes to the glycome) can improve the stratification of patients with prostate cancer [10].

Glycans are saccharides that can be attached to proteins, lipids, and other glycans through the enzymatic process known as glycosylation. Glycosylation is the most common posttranslational modification, and is now known to be essential to virtually every biological process in the body [11]. Glycans can either be added sequentially to the hydroxyl oxygen of serine/threonine residues on the target protein (O-linked glycosylation), or as pre-assembled blocks of 14 sugars that are transferred co-translationally via the amide group of an asparagine residue on the target protein ( $\mathrm{N}$-linked glycosylation). How much a protein or lipid is glycosylated depends on the number of glycosylation sites present, and the expression of specific glycosylation enzymes within the cell [9]. Glycans are major building blocks of life [12], but have been hugely understudied (Figure 1). This is partly due to their complexity, the difficulties studying them, and that there is no clear link between glycans and DNA. However, this is now changing, and the importance of glycans can be conceptualised as an extended model of the central dogma (Figure 2). The technology to study glycans is rapidly advancing, and there is expected to be an explosion of interest in this area in the next 10 to 15 years, which will be helped by projects such as the human glycome project [13].
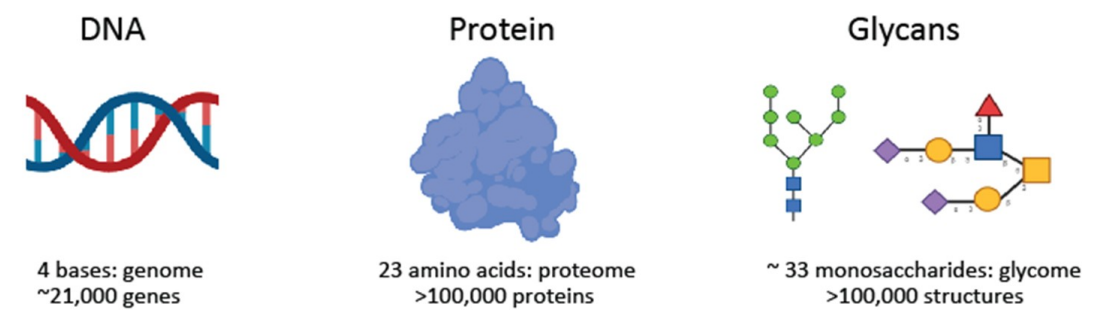

Figure 1. Glycans, the understudied major building blocks of life. The glycoproteome combines three highly adaptable interdependent biological alphabets. Created with BioRender.

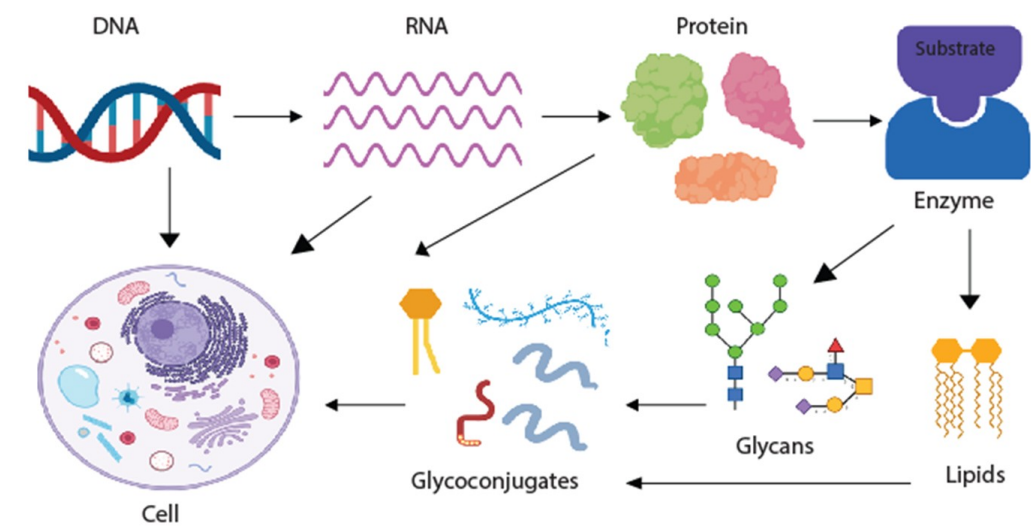

Figure 2. The importance of glycans can be conceptualised as an extended model of the central dogma. Created with BioRender. 
Changes to glycans in cancer cells were first described 50 years ago [14], and confirmed by the development of antibodies against tumour-specific antigens [15]. Aberrant glycosylation is a universal feature of cancer cells, and cancer-associated glycans have been detected in virtually every cancer type $[16,17]$. Cancer cells have numerous changes to glycans compared to normal tissue, including changes to sialylation, fucosylation, the truncation of O-glycans, and N-glycan branching (see [18] for more details). The importance of glycans in cancer is emphasised by the majority of the Food and Drug Administration (FDA)-approved tumour markers being glycan antigens or glycoproteins [19-21]. Glycans have key roles in fundamental molecular and cell biology processes in cancer biology, including cell signalling, tumour cell invasion, immune modulation, angiogenesis, interactions with the cell matrix, and metastasis, which are linked to all of the recognised cancer hallmarks [17]. Glycans secreted by cancer cells likely represent the altered glycosylation status of cancer cells, and are a largely untapped resource of cancer biomarkers. There is a huge potential to exploit glycans to improve early diagnosis, as biomarkers for prognosis and stratification, and as markers of specific therapeutic targets [7].

The physiological function of the prostate is to act as a secretory gland, which generates and secretes glycoproteins such as PSA into seminal fluid. As such, the prostate is a major secretor of glycans, and there is an unrealised opportunity to detect aberrant glycosylation patterns in serum and urine, and link this to prostate cancer status [22]. As prostate cancer progresses, the epithelial glands become smaller and more rounded, potentially having a drastic effect on the normal secretory pathways where proteins and lipids are glycosylated. Glycans can influence cell survival, proliferation, and metastasis, and likely play a key role in these processes in prostate cancer [22]. A wide range of alterations to glycans have been observed in prostate cancer, including changes to PSA glycosylation, increased sialylation and fucosylation, increased O-GlcNacylation, the emergence of cryptic and branched N-glyans, and changes to galectins and proteoglycans [22-24] (see Tables 1-3 for more details). In this review, we discuss the huge potential to exploit glycans as diagnostic and prognostic biomarkers for prostate cancer, and argue that it will be essential to include glycans as part of a multi-analyte liquid biopsy test.

\section{PSA Glycosylation}

Prostate-specific antigen (PSA) is a glycoprotein enzyme that has been used widely as a biomarker for prostate cancer, but has the disadvantage of low specificity and no prognostic value at diagnosis [25]. PSA screening for prostate cancer has led to the overdiagnosis and overtreatment of indolent disease, resulting in unnecessary biopsies and treatments for non-aggressive cancers [26,27]. Refinements on the PSA test, such as the Prostate Health Index (PHI) and 4Kscore, can improve diagnostic accuracy, but have limited prognostic utility, and may miss some high-grade cancers [28]. Thus, there is an urgent clinical need to shift the focus to identifying aggressive disease that needs immediate treatment [29-31]. Advances in mass spectrometry have led to an increased interest in glycan structures on cancer-associated proteins, and numerous studies have investigated whether a glycan signature on PSA can be used to improve its clinical utility [21,24]. A recent study also linked a single nucleotide polymorphism that affects PSA glycosylation to prostate cancer risk [32]. PSA has a single N-glycosylation site at asparagine-69 (Asn-69) [24]. Approximately 50 glycoforms of PSA have been described, but only some of these are found in aggressive prostate cancer. In particular, complex biantennary glycoforms with $\alpha 2,3$-sialic acid have been closely linked to aggressive disease in multiple studies [33-35] (Table 1). When combined with the PHI, the detection of $\alpha 2,3$-sialic acid PSA glycoforms in a cohort of 79 patients showed $100 \%$ sensitivity and $94.7 \%$ specificity to differentiate high-risk prostate cancer from low-risk and benign disease [34]. The robust prediction power of $\alpha 2,3$-sialylated PSA to diagnose aggressive prostate cancer has been confirmed by other studies using independent cohorts and different technologies [35]. Together, these studies provide strong evidence in support of the clinical utility of PSA glycoforms to distinguish indolent and aggressive prostate cancer. 


\section{Sialyled Glycans}

Sialylation is the process by which sialic acid residues are added to glycans as the terminal monosaccharide. Abnormal sialylation is a universal feature of cancer cells that is linked to poor prognosis and metastasis [9,36-40]. In prostate cancer, sialic acid levels have been investigated as an adjunct to PSA in predicting prostate malignancy [41,42]. Increased levels of $\alpha 2$-3-linked sialic acid have been detected on serum glycoproteins in patients with prostate cancer compared to benign prostatic hyperplasia (BPH), and can be used to predict Gleason score with a higher specificity and sensitivity than PSA [43,44]. Serum sialic acid levels have also been linked to pathological grade, and elevated sialic acid may predict bone metastasis [45]. Together, these studies suggest serum sialic acid as a promising diagnostic biomarker for prostate cancer that should be further investigated for use in predicting disease progression.

An emerging tool for glycoproteomic analysis is the use of azide sugar analogs as mimics of sialic acid. This strategy utilises metabolically labelled glycans with chemical reporters that are ligated to fluorescent probes, and offers a new avenue for probing changes to the glycome by both imaging and glycoproteomic analyses $[24,46]$. In prostate cancer, sialic acid analogs have been used to identify sialoglycoproteins linked to metastatic potential in cell lines derived from PC3 cells [47]. More recently, sugar azide analogs have been utilised in prostate cancer tissue slices to identify glycoproteins that are elevated or uniquely found in prostate cancer cells [48].

As well as changes to serum sialic acid levels and sialoglycoproteins, tumour-associated sialylated glycans also change in prostate cancer. Numerous studies have reported the upregulation of the sialylated blood group antigen Sialyl Lewis $\mathrm{X}\left(\mathrm{SLe}^{\mathrm{X}}\right)$ in prostate cancer, and linked this with poor prognosis in patients [49-52] (Table 1). SLe ${ }^{\mathrm{X}}$, and its isomer SLe ${ }^{\mathrm{A}}$, are the minimal recognition motif for ligands of selectins, which is a family of lectins with roles in leukocyte trafficking and tumour extravasation [53]. $\mathrm{SLe}^{\mathrm{X}}$ could influence prostate cancer progression through numerous mechanisms, including binding to E-selectin, the evasion of Natural Killer (NK) cell immunity, and the promotion of bone metastasis [52,54-56]. The upregulation of SLe ${ }^{\mathrm{X}}$ has been detected on PSA, Mucin 1 (MUC1), and prostatic acid phosphatase (PAP) proteins in a panel of 10 malignant tissues (relative to matched normal tissue), opening up a new avenue for the development of prostate cancer-specific glycoprotein biomarkers [57]. The cancer-associated sialyl-Tn glycan (known as sTn) has also been linked to prostate cancer. STn is a truncated O-glycan containing a sialic acid $\alpha-2,6$ linked to GalNAc $\alpha$-O-Serine/Threonine (Ser/Thr) (Table 1). The sTn glycan is upregulated in several cancer types and associated with metastasis and poor prognosis [37]. In prostate cancer, sTn is expressed in high-grade prostate tumours [58,59], and can reduce prostate cancer cell adhesion [60,61]. The sTn antigen is being widely investigated as a circulating biomarker for other cancers [62,63], and it is likely that innovative tools that were developed to detect sTn [63-65] will also have clinical utility for prostate cancer precision oncology.

Table 1. Summary of glycan alterations in prostate cancer. PSA: prostate-specific antigen.

\begin{tabular}{cclc}
\hline Glycan & Link to Prostate Cancer & References \\
\hline $\begin{array}{c}\text { Example of N-glycan on } \\
\text { PSA }\end{array}$ & $\begin{array}{l}\text { Complex biantennary } \\
\text { glycoforms with } \\
\alpha 2,3 \text {-sialic acid have } \\
\text { been closely linked to } \\
\text { aggressive disease in } \\
\text { multiple studies. }\end{array}$ & \\
& $\alpha 2-3$ sialylated N-glycan & \\
\hline
\end{tabular}


Table 1. Cont.

\begin{tabular}{|c|c|c|c|}
\hline Glycan & Structure & Link to Prostate Cancer & References \\
\hline Sialyl Lewis $\mathrm{X}\left(\mathrm{SLe}^{\mathrm{X}}\right)$ & sLex & $\begin{array}{l}\text { Upregulated and linked } \\
\text { to poor prognosis in } \\
\text { patients. Detected on } \\
\text { PSA, MUC1 and PAP in } \\
\text { malignant tissue }\end{array}$ & {$[49-52,57]$} \\
\hline Sialyl Tn (sTn) & Ser/Thr & $\begin{array}{l}\text { Expressed in high-grade } \\
\text { prostate tumours. Can } \\
\text { reduce prostate cancer } \\
\text { cell adhesion. }\end{array}$ & [58-61] \\
\hline \multirow{2}{*}{ Core Fucosylation } & \multirow{2}{*}{ 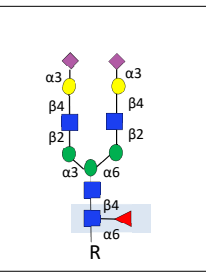 } & $\begin{array}{l}\text { Increased in patient } \\
\text { serum. Linked to } \\
\text { aggressive disease. }\end{array}$ & {$[43,66-68]$} \\
\hline & & $\begin{array}{l}\text { Levels correlate with } \\
\text { Fucosyltransferase } 8 \\
\text { (FUT8). }\end{array}$ & [69] \\
\hline \multirow{2}{*}{ O-GlcNAcylation } & \multirow[t]{2}{*}{ O-GIcNAc } & $\begin{array}{l}\text { Upregulated and linked } \\
\text { to poor prognosis in } \\
\text { primary prostate cancer. }\end{array}$ & {$[70,71]$} \\
\hline & & $\begin{array}{l}\text { Downregulated in } \\
\text { castrate resistant prostate } \\
\text { cancer(CRPC). }\end{array}$ & [72] \\
\hline \multirow{2}{*}{ Branched N-glycans } & \multirow{2}{*}{ 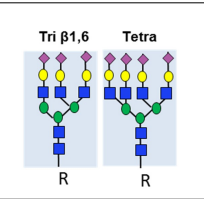 } & $\begin{array}{l}\text { Linked to metastasis and } \\
\text { disease-free survival. }\end{array}$ & [73] \\
\hline & & $\begin{array}{l}\text { Predictive biomarker for } \\
\text { CRPC. }\end{array}$ & [74] \\
\hline Cryptic N-glycans & Man5 & $\begin{array}{l}\text { N-linked oligomannose } 9 \\
\text { (Man9) is increased in } \\
\text { high-grade tumours and } \\
\text { linked to clinical } \\
\text { outcome. }\end{array}$ & [75] \\
\hline
\end{tabular}

\section{Fucosylation}

Fucosylation describes the attachment of a fucose residue to a glycan, and consists of terminal fucosylation and core fucosylation. Increased core fucosylation has been detected in the serum of patients with prostate cancer, is associated with disease progression $[43,67,68]$ (Table 1), and may influence prostate cancer cell trafficking through an E-selectin dependent mechanism [56]. The fucosyltransferase FUT8 is the only enzyme responsible for the $\alpha-1,6$-linked core fucosylation that adds fucose to the inner GlcNAc on N-glycans [76]. FUT8 expression is increased in high-grade and metastatic prostate cancer $[73,77]$. The increased fucosylation of glycoproteins in aggressive prostate cancer correlates with FUT8 [69], and this has been recently linked to castrate resistance, cell survival, and lower PSA production [78] (Table 1). Taken together, these findings implicate dysregulated fucosylation in prostate cancer progression and the development of castrate resistance. In line with this, several fucosylated glycoproteins are being investigated as potential non-invasive predictive biomarkers. These include decreased fucosylation on PSA [33,79] and integrins [80], and elevated fucosylated haptoglobin [68]. 


\section{O-GlcNAcylation}

The addition of O-GlcNAc to proteins (known as O-GlcNAcylation) plays a fundamental role in cellular processes, including transcription, epigenetics, cell signalling, proteostasis, and bioenergetics [81,82] (Table 1). In cancer cells, elevated pools of Uridine diphosphate $\mathrm{N}$-acetylglucosamine (UDP-GlcNAc) drive the O-GlcNAcylation of key targets in the cytoplasm, nucleus, and mitochondrion, and can alter key hallmarks of cancer [83,84]. O-GlcNAcylation is catalysed by O-GlcNAc transferase (OGT) (for more details, see [85]). OGT uses UDP-GlcNAc as a substrate, which is produced by the hexosamine biosynthetic pathway (HBP). HBP acts as a sensor for the nutritional state of the cell, and has a key role in the metabolic rewiring observed in cancer [86]. In primary prostate cancer, global O-GlcNAcylation is elevated relative to benign disease [70], and O-GlcNAc levels correlate with a higher Gleason score and reduced patient prognosis [71]. Both OGT and enzymes in the HBP pathway change in prostate cancer. OGT is upregulated in primary prostate cancer, and this is linked to a higher Gleason score, reduced time to biochemical recurrence, and increased c-Myc stability [87]. Similarly, UDP-N-Acetylglucosamine Pyrophosphorylase 1 (UAP1,the last enzyme in the HBP) is also overexpressed in prostate cancer tissue [88]. Although HBP is upregulated in localised prostate cancer where it promotes disease progression, in advanced castrate-resistant disease, the inhibition of HBP enhances tumour growth [72]. Metabolic rewiring during disease progression is believed to promote the downregulation of HBP in castrate-resistant disease, and in particular, loss of the Glucosamine-Phosphate N-Acetyltransferase 1 (GNPNAT1) enzyme may serve as a marker of progression to castrate resistance [72].

\section{Branched and Cryptic N-Glycans}

Changes to $\mathrm{N}$-glycans are common in cancer, and have been linked to metastasis in multiple tumour types $[89,90]$. Common changes include the branching of complex biantennary glycans to triantennary and tetraantennary structures, and the emergence of cryptic N-glycans [9] (Table 1). In prostate cancer, $\beta-1,6-$ GlcNAc tri-branched and tetra-branched N-glycans are linked to both metastasis in xenograft models and disease-free survival in patients [73]. Serum N-glycan signatures have shown promise as diagnostic and predictive biomarkers in prostate cancer [91]. Changes to branched N-glycans can help distinguish BPH and prostate cancer [43,92], and increased serum triantennary and tetraantennary $\mathrm{N}$-glycans have clinical utility to predict castrate-resistant prostate cancer [74]. In recent work, a muti-omic study identified tetraantennary and tetrasialylated N-glycans using mass specrometery as part of a biomarker panel to improve the stratification of patients with indolent and aggressive prostate cancer, and predict patient survival [10].

Cryptic N-glycans are the precursors, cores, and internal sequences of N-glycans that are usually masked by other sugar moieties, but occur in cancer due to alterations in glycan synthesis and processing [22,93]. As illustrated in Table 1, they contain the same mannose cores, but differ in the terminal sugar moieties. Cryptic N-glycans expose internal sequences that are normally 'cryptic' to the immune system [94]. Several studies have investigated how cryptic N-glycans change among different Gleason grades of prostate cancer and in metastatic disease [73,94-96]. Of particular interest, the cryptic N-glycan Man9 has been detected in the serum of men with prostate cancer, and serum Man9 autoantibodies may help differentiate high-grade tumours and predict clinical outcome [75]. The further development and validation of assays to detect anti-Man9 antibodies in patient serum is expected to be useful clinically.

\section{The F77 Antigen}

An antibody against the F77 antigen was initially isolated from mice injected with PC3 cells, and has provoked great interest as a prostate cancer-specific diagnostic and therapeutic tool. F77 was first identified as a glycolipid with $\alpha 1,2$-fucose linkages, and linked to the glycosylation enzymes Fucosyltransferase 1 (FUT1) and Core 2 Branching Enzymes 1-3 (GCNT1, GCNT2, and GCNT3) [97-99]. 
However, F77 has since been detected on O-glycan proteins, including a spliced isoform of CD44 found in the sera of prostate cancer patients [100]. The antibody against F77 can inhibit the growth of PC3 and DU145 tumour xenografts in nude mice, and can be used to differentiate primary and metastatic prostate cancer from non-malignant prostate tissue, [99]. Immunohistochemistry staining tissue sections detected F77 in 112 of 116 primary and 29 of 34 metastatic prostate cancer tissues, while no signal was detected in normal prostate tissue [99].

\section{Glycolipids}

Many of the glycans found attached to proteins are also found on glycolipids (glycolipids are lipids modified by one or more glycans). The aberrant expression of glycolipids in cancer has potential roles in disease progression and anti-tumour immunity (see [101] for more details). In prostate cancer, the F77 antigen (see Section 7 above) is known to contain a glycolipid with $\alpha 1,2$-fucose linkages, and preliminary studies have linked increased ganglioside GD1a to castrate-resistant disease [102,103].

\section{Proteoglycans}

Proteoglycans are proteins that are heavily glycosylated. The core protein has one or more glycosaminoglycan (GAG) chains attached (such as chondroitin sulphate, heparin sulphate, or keratin sulphate). Proteoglycans are a major component of the extracellular matrix and interact with growth factors, chemokines, and other extracellular matrix proteins. They have roles in cell signalling, adhesion, cell growth, and apoptosis, and have an established role in cancer progression [104]. Several proteoglycans have been found to be important in prostate cancer, including versican, decorin, biglycan, lumican, and syndecan-1 (summarised in Table 2), and data from a range of studies implicate proteoglycan alterations to prostate cancer cell survival and metastasis [105]. Proteoglycan expression patterns might be useful as predictive and prognostic biomarkers in patients with prostate tumours [22]. Of particular interest, increased levels of versican [106], biglycan [107], and syndecan-1 [108,109] are linked to poor prognosis.

Table 2. Proteoglycans with roles in prostate cancer.

\begin{tabular}{|c|c|c|}
\hline Proteoglycan & Link to Prostate Cancer & References \\
\hline Versican & $\begin{array}{l}\text { Modulates binding to the extracellular matrix (ECM) and } \\
\text { enhances motility. } \\
\text { Associated with poor prognosis. }\end{array}$ & {$[106,110-112]$} \\
\hline Decorin & $\begin{array}{l}\text { Suppresses tumour growth by inhibiting both androgen } \\
\text { receptor (AR) and epidermal growth factor (EGF). } \\
\text { Decreased in prostate cancer. }\end{array}$ & {$[106,113,114]$} \\
\hline Biglycan & Associated with poor prognosis and PTEN deletion. & [107] \\
\hline Lumican & $\begin{array}{l}\text { Lumican in stroma tissue suppresses cancer progression. } \\
\text { Potential marker in prostate cancer staging. }\end{array}$ & [115] \\
\hline Perlecan & $\begin{array}{l}\text { Linked to disease progression. Upregulates sonic } \\
\text { hedgehog signalling. }\end{array}$ & {$[116,117]$} \\
\hline \multirow[t]{2}{*}{ Syndecan-1 } & $\begin{array}{l}\text { Role in the epithelial-to-mesenchymal transition (EMT). } \\
\text { Maintains stability of prostate tumour initiating cells. }\end{array}$ & {$[118,119]$} \\
\hline & Poor prognosis. & {$[108,109]$} \\
\hline
\end{tabular}

\section{Galectins}

Cancer cells may also display altered expression of proteins that interact with glycans. A key example of this is the galectins, which are a group of glycan-binding proteins with an established role in tumour biology [120]. Several galectins have been implicated in prostate cancer biology (summarised in Table 3). A unique galectin signature has been identified in prostate cancer tissue, with 
the upregulation of galectin-1 and downregulation of galectins 3, 4, 9, and 12 observed during disease progression [121]. Of particular interest, galectin-3 is linked to tumour progression [122] and has a role in the prostate cancer bone metastasis niche [123]. Immunohistochemistry staining of galectin-3 in tissues from 83 patients had $91.7 \%$ sensitivity, $64 \%$ specificity, and $73 \%$ accuracy in predicting PSA biochemical recurrence [124].

Table 3. Galectins with roles in prostate cancer.

\begin{tabular}{ccc}
\hline Galectin & Link to Prostate Cancer & References \\
\hline \multirow{2}{*}{ Galectin-1 } & Upregulated during disease progression. Linked to angiogenesis. & {$[121]$} \\
\cline { 2 - 3 } & Promotes prostate tumour growth and invasion. & {$[125,126]$} \\
\hline \multirow{2}{*}{ Galectin-3 } & $\begin{array}{c}\text { Potential diagnostic marker. } \\
\end{array}$ & {$[127]$} \\
\cline { 2 - 3 } & May in early stages, lost in advanced disease. & {$[123,124]$} \\
\hline Galectin-4 & Role in bone metastasis niche. & {$[122]$} \\
\cline { 2 - 3 } & Part of O-glycosylation-mediated signalling circuit drives & {$[128]$} \\
\hline Galectin-8 & Linketastatic CRPC. & {$[129]$} \\
\hline
\end{tabular}

\section{Upregulation of Glycosylation Enzymes}

One of the underlying causes of aberrant glycosylation in cancer is the dysregulated expression of glycosylation enzymes within the cancer cell [16]. Growing evidence links the differential expression of glycosylation enzymes to the progression of prostate cancer $[57,78,88,131-136]$ (summarised in Table 4). Androgens are known to drive the development and progression of prostate cancer, and the first line of treatment for men with advanced disease is androgen deprivation therapy (ADT) [137]. Recently, we identified a set of glycosylation enzymes that were regulated by androgens both in seven men undergoing ADT, and in prostate cancer cell lines. Importantly, these enzymes are linked to prostate cancer cell survival, and are upregulated in primary prostate cancer relative to normal and benign tissue $[131,132]$. The androgen-regulated glycosylation enzymes in prostate cancer include: (i) ST6GalNac1, which synthesises the cancer-associated sTn antigen, (ii) GCNT1, which is linked to the synthesis of sLe ${ }^{X}$, (iii) GalNAc transferase 7 (GALNT7), which is part of a gene signature associated with androgen receptor splice variant-7 (AR-V7), and (iv) the HBP enzyme UAP1, which is highly overexpressed in prostate cancer $[57,60,88,132,138]$. Several cancer-associated glycans, including sTn, $\mathrm{Tn}$, and sLe $\mathrm{X}^{\mathrm{X}}$ are also androgen regulated in prostate cancer cell lines [132], but this is yet to be studied in primary patient tissue. Preliminary studies have found that GCNT1 can be detected in post-digital rectal examination (post-DRE) urine from 35 prostate cancer patients by immunoblotting, and used to predict the extracapsular extension of prostate cancer (the receiver operating characteristic (ROC) curve analysis for GCNT1 was 0.7614 , compared to 0.7455 for PSA) [139]. The UAP1 gene can also be detected in plasma and urine, and can be used as part of a gene panel to predict prostate biopsy results and prognosis $[140,141]$. Altered expression of the fucosyltransferases FUT6 and FUT8 are important in advanced prostate cancer. FUT6 is upregulated in distant metastases, and may play a role in metastasis to bone [136]. FUT8 expression increases in aggressive and castrate-resistant prostate cancer, and is linked to poor prognosis in patients (these studies were based on cell lines, and a small number of tissue samples and will need repeating in additional larger cohorts) [77,78]. Taken together, these studies suggest that glycosylation enzymes are a promising but yet unexploited resource of diagnostic and prognostic biomarkers for prostate cancer, and may also provide new insights into candidate glycoprotein alterations. 
Table 4. Summary of glycosylation enzymes with roles in prostate cancer. HBP: hexosamine biosynthetic pathway.

\begin{tabular}{|c|c|c|c|}
\hline $\begin{array}{l}\text { Glycosylation } \\
\text { Enzyme }\end{array}$ & Role in Glycosylation & Link to Prostate Cancer & References \\
\hline ST6GALNAC1 & $\begin{array}{l}\text { Transfers } \alpha-2,6 \text { sialic acid } \\
\text { to O-linked GalNAc }\end{array}$ & $\begin{array}{l}\text { Regulated by androgens. Upregulated in } \\
\text { tumour tissue. Linked to the synthesis of } \\
\text { sTn. Reduced cell adhesion }\end{array}$ & {$[60,61,142]$} \\
\hline \multirow{6}{*}{ GCNT1 } & \multirow{6}{*}{$\begin{array}{l}\text { Forms core-2-branched } \\
\text { O-linked glycans }\end{array}$} & $\begin{array}{l}\text { Increased in aggressive disease. Closely } \\
\text { related to extraprostatic extension and } \\
\text { lymph node metastasis. Increases tumour } \\
\text { growth on orthotopic inoculation into the } \\
\text { mouse prostate. }\end{array}$ & {$[133,134]$} \\
\hline & & Resistance to NK cell immunity. & [52] \\
\hline & & Regulated by androgens & [132] \\
\hline & & $\begin{array}{c}\text { Associated with higher levels of core } 2 \mathrm{O} \\
\text { sLex in PSA, PAP, and MUC1 }\end{array}$ & [57] \\
\hline & & Linked to F77 antigen. & [97] \\
\hline & & $\begin{array}{l}\text { Detected in post-DRE urine. Indicator of } \\
\text { extracapsular extension }\end{array}$ & [139] \\
\hline GCNT2 & $\begin{array}{l}\text { Forms core-2-branched } \\
\text { O-linked glycans }\end{array}$ & $\begin{array}{l}\text { Linked to invasion. Potential role in } \\
\text { integrin signalling. }\end{array}$ & [143] \\
\hline \multirow{3}{*}{ GALNT7 } & \multirow{3}{*}{$\begin{array}{l}\text { Initiation of } \\
\text { O-glycosylation }\end{array}$} & $\begin{array}{l}\text { Upregulated in malignant PCa as part of a } \\
\text { glycosylation gene signature. }\end{array}$ & [144] \\
\hline & & $\begin{array}{l}\text { Androgen regulated and linked to prostate } \\
\text { cancer cell viability. }\end{array}$ & [132] \\
\hline & & Correlates with AR-V7 in CRPC. & [138] \\
\hline C1GALT1 & $\begin{array}{l}\text { Generates the common } \\
\text { core } 1 \text { O-glycan structure }\end{array}$ & $\begin{array}{l}\text { Part of O-glycosylation mediated signalling } \\
\text { circuit that drives CRPC and is linked to } \\
\text { poor survival. }\end{array}$ & [129] \\
\hline \multirow[t]{2}{*}{ ST6Gal1 } & \multirow{2}{*}{$\begin{array}{l}\text { Addition of sialic acid to } \\
\text { galactose-containing } \\
\text { N-glycan }\end{array}$} & $\begin{array}{l}\text { Upregulated. Linked to reduced survival } \\
\text { and metastasis. }\end{array}$ & [135] \\
\hline & & Regulated by androgens. & [132] \\
\hline \multirow{2}{*}{ EDEM3 } & \multirow{2}{*}{$\begin{array}{l}\text { Mannose trimming of } \\
\text { N-glycans }\end{array}$} & $\begin{array}{l}\text { Upregulated in malignant prostate cancer } \\
\text { as part of a glycosylation gene signature. }\end{array}$ & [144] \\
\hline & & $\begin{array}{l}\text { Androgen regulated and linked to prostate } \\
\text { cancer cell viability. }\end{array}$ & [132] \\
\hline MGAT5 & $\begin{array}{l}\text { Biosynthesis of } \beta 1,6 \\
\text { GlcNAc-branched } \\
\text { N-glycans }\end{array}$ & Link to metastasis in mouse models. & [145] \\
\hline UAP1 & $\begin{array}{l}\text { Last enzyme in HBP } \\
\text { pathway. Produces } \\
\text { UDP-GlcNAc }\end{array}$ & $\begin{array}{l}\text { Highly overexpressed (correlates negatively } \\
\text { with Gleason score). Linked to increased } \\
\text { UDP-GlcNAc. Protects prostate cancer cells } \\
\text { from endoplasmic reticulum (ER) stress. } \\
\text { Regulated by androgens. }\end{array}$ & [88] \\
\hline GNPNAT1 & $\begin{array}{l}\text { HBP pathway. Produces } \\
\text { UDP-GlcNAc }\end{array}$ & GNPNAT1 is decreased in CRPC. & [72] \\
\hline FUT6 & Fucosylation & $\begin{array}{l}\text { Upregulated in distant metastases. Role in } \\
\text { prostate cancer metastasis to bone. }\end{array}$ & [136] \\
\hline \multirow[t]{2}{*}{ FUT8 } & \multirow{2}{*}{$\begin{array}{l}\text { Transfers fucose to } \\
\text { core-GlcNAc of the } \\
\text { N-glycans }\end{array}$} & $\begin{array}{l}\text { Increased in aggressive prostate cancer and } \\
\text { linked to poor prognosis. }\end{array}$ & [77] \\
\hline & & Increased in CRPC. & {$[78]$} \\
\hline
\end{tabular}




\section{Exosomes}

Exosomes are small vesicles secreted from most cell types that are present in body fluids. There is increasing evidence that exosomes are involved in carcinogenesis, and they are emerging as a rich source of tumour-specific proteins and biomarkers for cancer detection and progression [146]. Exosomes secreted by the prostate are structurally unique, and can be isolated from seminal fluid, tissue, blood, or urine for further analyses, providing a novel and easily isolatable source of tumour-specific proteins [147]. Glycans are important in exosome function [148]. A recent review discussed the potential to exploitexosomes as powerful tools to diagnose aggressive prostate cancer as early as possible, as well as predict patient prognosis and response to treatment [149]. Exosomes are a rich source of glycans $[23,150]$, but are still largely unexplored in prostate cancer. The profiling of N-linked glycans from prostate cancer exosomes indicates a global decrease in large branched triantennary and tetraantennary glycans that reflects clinical status [151]. A better understanding of the presence of glycoproteins and glycan profiles of exosomes could improve current approaches of diagnosis and prognosis. As discussed by Tkac et al., glycan markers are likely to be enriched in exosomes, which will aid in assay design [23].

\section{Tissue Imaging of Glycans}

Changes to glycans can be profiled in clinically relevant tissues using recently developed innovative approaches. A sialyltransferase-based chemoenzymatic histology assay can detect differences between unsialylated glycans in normal, cancerous, and metastatic prostate tissue sections [152], and bioorthoganol labelling has been used to identify sialoglycoproteins in prostate cancer tissue slices [48]. Advances in imaging mass spectrometry mean that glycans can now be identified directly on patient tissue, allowing for analysis of the spatial distribution of glycans. $\mathrm{N}$-glycans can be profiled on formalin-fixed paraffin embedded (FFPE) tissue samples and tissue microarrays (TMAs) using matrix-assisted laser desorption/ionization imaging mass spectrometry (MALDI-IMS) [24,153-155]. In this recently developed approach, glycans are released from their protein carrier and analysed directly on tissue. More than 40 individual glycan structures can be detected, and tumour-specific glycans can be grouped relative to histopathology localisations [155]. A major advantage of MALDI-MS imaging is that the best starting material is FFPE tissue, which is widely available in pathology labs. Ongoing work in this emerging area aims to identify tumour-specific glycan biomarker panels indicative of aggressive prostate cancer, as well as identify a second tier of biomarkers by linking glycans back to their original glycoprotein carriers [23]. It is hoped that information on the various types of glycans within cancer tissue can be used in the future to enable the development of lectin-based assays for use in the pathology lab [155].

\section{A Multi-Omic Liquid Biopsy Test}

The development and progression of prostate cancer from localised, organ-confined disease to biochemically progressive and then to metastasis is prolonged. To capture this evolving landscape, serial tissue biopsies are needed, which is difficult and costly to execute in the clinic. In addition, prostate cancer preferentially metastasises to bone, which is a site that is very difficult to sample. Tumour heterogeneity can also lead to aggressive tumours being missed, or underestimation of the tumour landscape [156]. Liquid biopsies offer a potential solution to overcome the practical and technical challenges of the traditional tissue biopsy [157]. The concept of a 'liquid biopsy' relies on the principle that cancer cells are shed directly into blood, urine, and other body fluids. These cancer cells can be captured and used to derive information to improve diagnosis, prognosis, or treatment. Liquid biopsies may also capture a more complete representation of a cancer, which encompasses tumour heterogeneity [158]. 
Flow cytometery techniques were able to detect circulating prostate cancer cells in men with metastatic disease as early as the 1970s [159]. Today, technologies can use bodily fluids to profile genomic mutations, copy number alterations, and obtain information about the tumour transcriptome, epigenome, proteome, metabalome, and glycome. Among prostate cancer liquid biopsies, circulating tumours cells (CTCs) are the most extensively evaluated biomarkers [160], but other clinically relevant phenotypes have also shown promise. These include detection of the androgen receptor variant V7 (AR-V7) [161], circulating miRNAs [162-164], TMPRSS2:ERG, and prostate cancer antigen 3 (PCA3) [165-167], circulating free DNA (cfDNA) (reviewed in [158]), detection of gene methylation [168,169], and the analysis of tumour-derived exosomes [170].

Individual biomarkers in liquid biopsy can often not accurately predict disease state due to heterogeneity in phenotype across individuals and over time. To address this challenge, effective diagnostics using liquid biopsies will require multiparameter strategies to combine information from multiple analytes. A recent study by Murphy et al. suggested that integrating biomarkers across multi-omic platforms (including changes to the epigenome, transcriptome, proteome, and glycome) can improve the stratification of patients with prostate cancer [10]. By the analysis of four types of DNA methylation, four coding and nine non-coding RNAs, 27 peptides, and 13 glycans (in a cohort of 158 radical prostatectomy patients), combined with clinical parameters, it was possible to effectively distinguish indolent and aggressive prostate cancer with area under the ROC curve (AUC) $=0.91$ (age, PSA level, Gleason score, and DRE gave an AUC of 0.67). This strongly suggests that multivariate models (built from different -omics data) will lead to superior accuracy over individual markers for prostate cancer diagnosis and disease stratification [10], and together with the data discussed in this review, clearly demonstrate that the inclusion of glycans in a multi-analyte liquid biopsy test for prostate cancer should help improve clinical utility.

\section{Conclusions and Future Perspectives}

Glycans contribute to many aspects of prostate cancer, and likely represent a huge and largely untapped resource of biomarkers with clinical utility. The summary provided by this review suggests that glycan-based biomarkers should be exploited as powerful tools to diagnose prostate cancer as soon as possible, and to accurately determine tumour aggressiveness and patient prognosis. Liquid biopsies hold great potential as non-invasive assays to monitor tumour heterogeneity and evolution, and select personalised therapy. As new markers are identified, their clinical impact must be translated through assay development, followed by clinical reproducibility and sensitivity testing [171]. These efforts raise new biological and technical challenges [158,172], yet constitute critical steps towards precision oncology. The ultimate goal in the field will be to clinically validate several types of molecules, including glycans, within a multi-analyte liquid biopsy test. Furthermore, looking towards the future, artificial intelligence-based tools may be useful to automatically discover and detect these signatures and move the field towards multiparametric analyses [173]. Alongside this, the development of novel glycan-targeting drugs (for examples, see [174-179]) will likely lead to new personalised glycan-based therapies.

Funding: This work was supported by Prostate Cancer UK through a Research Innovation Award (RIA16-ST2-011).

Conflicts of Interest: The authors declare no conflict of interest.

\section{References}

1. Siegel, R.L.; Miller, K.D.; Jemal, A. Cancer statistics, 2016. CA Cancer J. Clin. 2016, 66, 7-30. [CrossRef]

2. Attard, G.; Parker, C.; Eeles, R.A.; Schroder, F.; Tomlins, S.A.; Tannock, I.; Drake, C.G.; de Bono, J.S. Prostate cancer. Lancet 2016, 387, 70-82. [CrossRef]

3. Jamaspishvili, T.; Kral, M.; Khomeriki, I.; Student, V.; Kolar, Z.; Bouchal, J. Urine markers in monitoring for prostate cancer. Prostate Cancer Prostatic Dis. 2010, 13, 12-19. [CrossRef] 
4. $\quad$ Drake, R.R.; White, K.Y.; Fuller, T.W.; Igwe, E.; Clements, M.A.; Nyalwidhe, J.O.; Given, R.W.; Lance, R.S.; Semmes, O.J. Clinical collection and protein properties of expressed prostatic secretions as a source for biomarkers of prostatic disease. J. Proteom. 2009, 72, 907-917. [CrossRef]

5. Crowley, E.; Di Nicolantonio, F.; Loupakis, F.; Bardelli, A. Liquid biopsy: Monitoring cancer-genetics in the blood. Nat. Rev. Clin. Oncol. 2013, 10, 472-484. [CrossRef]

6. Heitzer, E.; Haque, I.S.; Roberts, C.E.S.; Speicher, M.R. Current and future perspectives of liquid biopsies in genomics-driven oncology. Nat. Rev. Genet. 2018, 20, 71-88. [CrossRef]

7. Adamczyk, B.; Tharmalingam, T.; Rudd, P.M. Glycans as cancer biomarkers. Biochim. Biophys. Acta 2012, 1820, 1347-1353. [CrossRef]

8. Reis, C.A.; Osorio, H.; Silva, L.; Gomes, C.; David, L. Alterations in glycosylation as biomarkers for cancer detection. J. Clin. Pathol. 2010, 63, 322-329. [CrossRef]

9. Pinho, S.S.; Reis, C.A. Glycosylation in cancer: Mechanisms and clinical implications. Nat. Rev. Cancer 2015, 15, 540-555. [CrossRef]

10. Murphy, K.; Murphy, B.T.; Boyce, S.; Flynn, L.; Gilgunn, S.; O’Rourke, C.J.; Rooney, C.; Stockmann, H.; Walsh, A.L.; Finn, S.; et al. Integrating biomarkers across omic platforms: An approach to improve stratification of patients with indolent and aggressive prostate cancer. Mol. Oncol. 2018, 12, 1513-1525. [CrossRef]

11. Varki, A. Biological roles of glycans. Glycobiology 2017, 27, 3-49. [CrossRef]

12. Springer, S.A.; Gagneux, P. Glycan evolution in response to collaboration, conflict, and constraint. J. Biol. Chem. 2013, 288, 6904-6911. [CrossRef]

13. Hart, G.W.; Varki, A. Future directions in glycosciences. In Essentials of Glycobiology; Varki, A., Cummings, R.D., Esko, J.D., Stanley, P., Hart, G.W., Aebi, M., Darvill, A.G., Kinoshita, T., Packer, N.H., Prestergard, J.H., et al., Eds.; Cold Spring Harbor: Cold Spring Harbor, NY, USA, 2015; pp. 761-768.

14. Meezan, E.; Wu, H.C.; Black, P.H.; Robbins, P.W. Comparative studies on the carbohydrate-containing membrane components of normal and virus-transformed mouse fibroblasts. Ii. Separation of glycoproteins and glycopeptides by sephadex chromatography. Biochemistry 1969, 8, 2518-2524. [CrossRef]

15. Feizi, T. Carbohydrate antigens in human cancer. Cancer Surv. 1985, 4, 245-269.

16. Hauselmann, I.; Borsig, L. Altered tumor-cell glycosylation promotes metastasis. Front. Oncol. $2014,4,28$. [CrossRef]

17. Munkley, J.; Elliott, D.J. Hallmarks of glycosylation in cancer. Oncotarget 2016, 7, 35478-35489. [CrossRef]

18. Varki, A.; Kannagi, R.; Toole, B.; Stanley, P. Glycosylation changes in cancer. In Essentials of Glycobiology; Varki, A., Cummings, R.D., Esko, J.D., Stanley, P., Hart, G.W., Aebi, M., Darvill, A.G., Kinoshita, T., Packer, N.H., Prestergard, J.H., et al., Eds.; Cold Spring Harbor: Cold Spring Harbor, NY, USA, 2015; pp. 597-609.

19. Hammarstrom, S. The carcinoembryonic antigen (cea) family: Structures, suggested functions and expression in normal and malignant tissues. Semin. Cancer Biol. 1999, 9, 67-81. [CrossRef]

20. Moss, E.L.; Hollingworth, J.; Reynolds, T.M. The role of ca125 in clinical practice. J. Clin. Pathol. 2005, 58, 308-312. [CrossRef]

21. Gilgunn, S.; Conroy, P.J.; Saldova, R.; Rudd, P.M.; O'Kennedy, R.J. Aberrant psa glycosylation-A sweet predictor of prostate cancer. Nat. Rev. Urol. 2013, 10, 99-107. [CrossRef]

22. Munkley, J.; Mills, I.G.; Elliott, D.J. The role of glycans in the development and progression of prostate cancer. Nat. Rev. Urol. 2016, 13, 324-333. [CrossRef]

23. Tkac, J.; Bertok, T.; Hires, M.; Jane, E.; Lorencova, L.; Kasak, P. Glycomics of prostate cancer: Updates. Expert Rev. Proteom. 2018, 16, 65-76. [CrossRef] [PubMed]

24. Drake, R.R.; Jones, E.E.; Powers, T.W.; Nyalwidhe, J.O. Chapter ten-Altered glycosylation in prostate cancer. Adv. Cancer Res. 2015, 126, 345-382.

25. Barry, M.J. Screening for prostate cancer-The controversy that refuses to die. N. Engl. J. Med. 2009, 360, 1351-1354. [CrossRef] [PubMed]

26. Etzioni, R.; Penson, D.F.; Legler, J.M.; di Tommaso, D.; Boer, R.; Gann, P.H.; Feuer, E.J. Overdiagnosis due to prostate-specific antigen screening: Lessons from U.S. Prostate cancer incidence trends. J. Natl. Cancer Inst. 2002, 94, 981-990. [CrossRef]

27. Lilja, H.; Ulmert, D.; Vickers, A.J. Prostate-specific antigen and prostate cancer: Prediction, detection and monitoring. Nat. Rev. Cancer 2008, 8, 268-278. [CrossRef] 
28. Nordstrom, T.; Vickers, A.; Assel, M.; Lilja, H.; Gronberg, H.; Eklund, M. Comparison between the four-kallikrein panel and prostate health index for predicting prostate cancer. Eur. Urol. 2015, 68, 139-146. [CrossRef]

29. Prensner, J.R.; Rubin, M.A.; Wei, J.T.; Chinnaiyan, A.M. Beyond psa: The next generation of prostate cancer biomarkers. Sci. Transl. Med. 2012, 4, 127rv3. [CrossRef] [PubMed]

30. Shariat, S.F.; Semjonow, A.; Lilja, H.; Savage, C.; Vickers, A.J.; Bjartell, A. Tumor markers in prostate cancer i: Blood-based markers. Acta Oncol. 2011, 50 (Suppl. 1), 61-75. [CrossRef]

31. Sountoulides, P.; Moutzouris, G. Prostate-specific antigen screening, why have the guidelines changed? Expert Rev. Anticancer Ther. 2014, 14, 1277-1281. [CrossRef]

32. Srinivasan, S.; Stephens, C.; Wilson, E.; Panchadsaram, J.; DeVoss, K.; Koistinen, H.; Stenman, U.H.; Brooks, M.N.; Practical, C.; Buckle, A.M.; et al. Prostate cancer risk-associated single-nucleotide polymorphism affects prostate-specific antigen glycosylation and its function. Clin. Chem. 2018, 65, e1-e9. [CrossRef]

33. Llop, E.; Ferrer-Batalle, M.; Barrabes, S.; Guerrero, P.E.; Ramirez, M.; Saldova, R.; Rudd, P.M.; Aleixandre, R.N.; Comet, J.; de Llorens, R.; et al. Improvement of prostate cancer diagnosis by detecting psa glycosylation-specific changes. Theranostics 2016, 6, 1190-1204. [CrossRef] [PubMed]

34. Ferrer-Batalle, M.; Llop, E.; Ramirez, M.; Aleixandre, R.N.; Saez, M.; Comet, J.; de Llorens, R.; Peracaula, R. Comparative study of blood-based biomarkers, alpha2,3-sialic acid psa and phi, for high-risk prostate cancer detection. Int. J. Mol. Sci. 2017, 18, 845. [CrossRef]

35. Ishikawa, T.; Yoneyama, T.; Tobisawa, Y.; Hatakeyama, S.; Kurosawa, T.; Nakamura, K.; Narita, S.; Mitsuzuka, K.; Duivenvoorden, W.; Pinthus, J.H.; et al. An automated micro-total immunoassay system for measuring cancer-associated alpha2,3-linked sialyl n-glycan-carrying prostate-specific antigen may improve the accuracy of prostate cancer diagnosis. Int. J. Mol. Sci. 2017, 18, 470. [CrossRef]

36. Vajaria, B.N.; Patel, K.R.; Begum, R.; Patel, P.S. Sialylation: An avenue to target cancer cells. Pathol. Oncol. Res. 2016, 22, 443-447. [CrossRef] [PubMed]

37. Munkley, J. The role of sialyl-tn in cancer. Int. J. Mol. Sci. 2016, 17, 275. [CrossRef]

38. Baldus, S.E.; Zirbes, T.K.; Monig, S.P.; Engel, S.; Monaca, E.; Rafiqpoor, K.; Hanisch, F.G.; Hanski, C.; Thiele, J.; Pichlmaier, H.; et al. Histopathological subtypes and prognosis of gastric cancer are correlated with the expression of mucin-associated sialylated antigens: Sialosyl-lewis(a), sialosyl-lewis(x) and sialosyl-tn. Tumour Biol. 1998, 19, 445-453. [CrossRef]

39. Zhang, Z.; Wuhrer, M.; Holst, S. Serum sialylation changes in cancer. Glycoconj. J. 2018, 35, 139-160. [CrossRef] [PubMed]

40. Munkley, J. The glycosylation landscape of pancreatic cancer (review). Oncol. Lett. 2019, 17, $2569-2575$. [CrossRef]

41. Michalakis, K.; Ilias, I.; Triantafyllou, A.; Polymeris, A.; Kastriotis, I.; Chairakaki, A.D.; Savopoulos, C. Detection of prostate cancer by sialic acid level in patients with non-diagnostic levels of prostate-specific antigen. Maturitas 2012, 73, 325-330. [CrossRef]

42. El Melegy, N.T.; Aboulella, H.A.; Abul-Fadl, A.M.; Mohamed, N.A. Potential biomarkers for differentiation of benign prostatic hyperplasia and prostate cancer. Br. J. Biomed. Sci. 2010, 67, 109-112. [CrossRef]

43. Saldova, R.; Fan, Y.; Fitzpatrick, J.M.; Watson, R.W.; Rudd, P.M. Core fucosylation and alpha2-3 sialylation in serum n-glycome is significantly increased in prostate cancer comparing to benign prostate hyperplasia. Glycobiology 2011, 21, 195-205. [CrossRef]

44. Ohyama, C.; Hosono, M.; Nitta, K.; Oh-eda, M.; Yoshikawa, K.; Habuchi, T.; Arai, Y.; Fukuda, M. Carbohydrate structure and differential binding of prostate specific antigen to maackia amurensis lectin between prostate cancer and benign prostate hypertrophy. Glycobiology 2004, 14, 671-679. [CrossRef]

45. Zhang, C.; Yan, L.; Song, H.; Ma, Z.; Chen, D.; Yang, F.; Fang, L.; Li, Z.; Li, K.; Li, D.; et al. Elevated serum sialic acid levels predict prostate cancer as well as bone metastases. J. Cancer 2019, 10, 449-457. [CrossRef] [PubMed]

46. Laughlin, S.T.; Bertozzi, C.R. Imaging the glycome. Proc. Natl. Acad. Sci. USA 2009, 106, 12-17. [CrossRef]

47. Yang, L.; Nyalwidhe, J.O.; Guo, S.; Drake, R.R.; Semmes, O.J. Targeted identification of metastasis-associated cell-surface sialoglycoproteins in prostate cancer. Mol. Cell. Proteom. 2011, 10, M110-007294. [CrossRef] [PubMed] 
48. Spiciarich, D.R.; Nolley, R.; Maund, S.L.; Purcell, S.C.; Herschel, J.; Iavarone, A.T.; Peehl, D.M.; Bertozzi, C.R. Bioorthogonal labeling of human prostate cancer tissue slice cultures for glycoproteomics. Angew. Chem. Int. Ed. Engl. 2017, 56, 8992-8997. [CrossRef]

49. Culig, Z.; Hittmair, A.; Hobisch, A.; Bartsch, G.; Klocker, H.; Pai, L.H.; Pastan, I. Expression of lewis carbohydrate antigens in metastatic lesions from human prostatic carcinoma. Prostate 1998, 36, 162-167. [CrossRef]

50. Jorgensen, T.; Berner, A.; Kaalhus, O.; Tveter, K.J.; Danielsen, H.E.; Bryne, M. Up-regulation of the oligosaccharide sialyl lewisx: A new prognostic parameter in metastatic prostate cancer. Cancer Res. 1995, 55, 1817-1819. [PubMed]

51. Khabaz, M.N.; McClure, J.; McClure, S.; Stoddart, R.W. Glycophenotype of prostatic carcinomas. Folia Histochem. Cytobiol. 2010, 48, 637-645.

52. Okamoto, T.; Yoneyama, M.S.; Hatakeyama, S.; Mori, K.; Yamamoto, H.; Koie, T.; Saitoh, H.; Yamaya, K.; Funyu, T.; Fukuda, M.; et al. Core2 o-glycan-expressing prostate cancer cells are resistant to nk cell immunity. Mol. Med. Rep. 2013, 7, 359-364. [CrossRef]

53. Natoni, A.; Macauley, M.S.; O’Dwyer, M.E. Targeting selectins and their ligands in cancer. Front. Oncol. 2016, 6, 93. [CrossRef] [PubMed]

54. Dimitroff, C.J.; Lechpammer, M.; Long-Woodward, D.; Kutok, J.L. Rolling of human bone-metastatic prostate tumor cells on human bone marrow endothelium under shear flow is mediated by e-selectin. Cancer Res. 2004, 64, 5261-5269. [CrossRef] [PubMed]

55. Julien, S.; Ivetic, A.; Grigoriadis, A.; QiZe, D.; Burford, B.; Sproviero, D.; Picco, G.; Gillett, C.; Papp, S.L.; Schaffer, L.; et al. Selectin ligand sialyl-lewis $\mathrm{x}$ antigen drives metastasis of hormone-dependent breast cancers. Cancer Res. 2011, 71, 7683-7693. [CrossRef]

56. Barthel, S.R.; Wiese, G.K.; Cho, J.; Opperman, M.J.; Hays, D.L.; Siddiqui, J.; Pienta, K.J.; Furie, B.; Dimitroff, C.J. Alpha 1,3 fucosyltransferases are master regulators of prostate cancer cell trafficking. Proc. Natl. Acad. Sci. USA 2009, 106, 19491-19496. [CrossRef]

57. Chen, Z.; Gulzar, Z.G.; St Hill, C.A.; Walcheck, B.; Brooks, J.D. Increased expression of gcnt1 is associated with altered o-glycosylation of psa, pap, and muc1 in human prostate cancers. Prostate 2014, 74, 1059-1067. [CrossRef]

58. Myers, R.B.; Meredith, R.F.; Schlom, J.; LoBuglio, A.F.; Bueschen, A.J.; Wheeler, R.H.; Stockard, C.R.; Grizzle, W.E. Tumor associated glycoprotein-72 is highly expressed in prostatic adenocarcinomas. J. Urol. 1994, 152, 243-246. [CrossRef]

59. Genega, E.M.; Hutchinson, B.; Reuter, V.E.; Gaudin, P.B. Immunophenotype of high-grade prostatic adenocarcinoma and urothelial carcinoma. Mod. Pathol. 2000, 13, 1186-1191. [CrossRef] [PubMed]

60. Munkley, J.; Oltean, S.; Vodak, D.; Wilson, B.T.; Livermore, K.E.; Zhou, Y.; Star, E.; Floros, V.I.; Johannessen, B.; Knight, B.; et al. The androgen receptor controls expression of the cancer-associated stn antigen and cell adhesion through induction of st6galnac1 in prostate cancer. Oncotarget 2015, 6, 34358-34374. [CrossRef]

61. Munkley, J.; Elliott, D.J. Sugars and cell adhesion: The role of st6galnac1 in prostate cancer progression. Cancer Cell Microenviron. 2016, 3, e1174.

62. Lima, L.; Neves, M.; Oliveira, M.I.; Dieguez, L.; Freitas, R.; Azevedo, R.; Gaiteiro, C.; Soares, J.; Ferreira, D.; Peixoto, A.; et al. Sialyl-tn identifies muscle-invasive bladder cancer basal and luminal subtypes facing decreased survival, being expressed by circulating tumor cells and metastases. Urol. Oncol. 2017, 35, 675 e671-675 e678. [CrossRef]

63. Neves, M.; Azevedo, R.; Lima, L.; Oliveira, M.I.; Peixoto, A.; Ferreira, D.; Soares, J.; Fernandes, E.; Gaiteiro, C.; Palmeira, C.; et al. Exploring sialyl-tn expression in microfluidic-isolated circulating tumour cells: A novel biomarker and an analytical tool for precision oncology applications. New Biotechnol. 2019, 49, 77-87. [CrossRef]

64. Eavarone, D.A.; Al-Alem, L.; Lugovskoy, A.; Prendergast, J.M.; Nazer, R.I.; Stein, J.N.; Dransfield, D.T.; Behrens, J.; Rueda, B.R. Humanized anti-sialyl-tn antibodies for the treatment of ovarian carcinoma. PLoS ONE 2018, 13, e0201314. [CrossRef]

65. Prendergast, J.M.; Galvao da Silva, A.P.; Eavarone, D.A.; Ghaderi, D.; Zhang, M.; Brady, D.; Wicks, J.; DeSander, J.; Behrens, J.; Rueda, B.R. Novel anti-sialyl-tn monoclonal antibodies and antibody-drug conjugates demonstrate tumor specificity and anti-tumor activity. $m A b s$ 2017, 9, 615-627. [CrossRef] 
66. Totten, S.M.; Adusumilli, R.; Kullolli, M.; Tanimoto, C.; Brooks, J.D.; Mallick, P.; Pitteri, S.J. Multi-lectin affinity chromatography and quantitative proteomic analysis reveal differential glycoform levels between prostate cancer and benign prostatic hyperplasia sera. Sci. Rep. 2018, 8, 6509. [CrossRef]

67. Kyselova, Z.; Mechref, Y.; Al Bataineh, M.M.; Dobrolecki, L.E.; Hickey, R.J.; Vinson, J.; Sweeney, C.J.; Novotny, M.V. Alterations in the serum glycome due to metastatic prostate cancer. J. Proteome Res. 2007, 6, 1822-1832. [CrossRef] [PubMed]

68. Fujita, K.; Shimomura, M.; Uemura, M.; Nakata, W.; Sato, M.; Nagahara, A.; Nakai, Y.; Takamatsu, S.; Miyoshi, E.; Nonomura, N. Serum fucosylated haptoglobin as a novel prognostic biomarker predicting high-gleason prostate cancer. Prostate 2014, 74, 1052-1058. [CrossRef] [PubMed]

69. Shah, P.; Wang, X.; Yang, W.; Toghi Eshghi, S.; Sun, S.; Hoti, N.; Chen, L.; Yang, S.; Pasay, J.; Rubin, A.; et al. Integrated proteomic and glycoproteomic analyses of prostate cancer cells reveal glycoprotein alteration in protein abundance and glycosylation. Mol. Cell. Proteom. 2015, 14, 2753-2763. [CrossRef] [PubMed]

70. Gu, Y.; Gao, J.; Han, C.; Zhang, X.; Liu, H.; Ma, L.; Sun, X.; Yu, W. O-glcnacylation is increased in prostate cancer tissues and enhances malignancy of prostate cancer cells. Mol. Med. Rep. 2014, 10, 897-904. [CrossRef] [PubMed]

71. Kamigaito, T.; Okaneya, T.; Kawakubo, M.; Shimojo, H.; Nishizawa, O.; Nakayama, J. Overexpression of o-glcnac by prostate cancer cells is significantly associated with poor prognosis of patients. Prostate Cancer Prostatic Dis. 2014, 17, 18-22. [CrossRef]

72. Kaushik, A.K.; Shojaie, A.; Panzitt, K.; Sonavane, R.; Venghatakrishnan, H.; Manikkam, M.; Zaslavsky, A.; Putluri, V.; Vasu, V.T.; Zhang, Y.; et al. Inhibition of the hexosamine biosynthetic pathway promotes castration-resistant prostate cancer. Nat. Commun. 2016, 7, 11612. [CrossRef]

73. Lange, T.; Ullrich, S.; Muller, I.; Nentwich, M.F.; Stubke, K.; Feldhaus, S.; Knies, C.; Hellwinkel, O.J.; Vessella, R.L.; Abramjuk, C.; et al. Human prostate cancer in a clinically relevant xenograft mouse model: Identification of beta(1,6)-branched oligosaccharides as a marker of tumor progression. Clin. Cancer Res. 2012, 18, 1364-1373. [CrossRef]

74. Ishibashi, Y.; Tobisawa, Y.; Hatakeyama, S.; Ohashi, T.; Tanaka, M.; Narita, S.; Koie, T.; Habuchi, T.; Nishimura, S.; Ohyama, C.; et al. Serum tri- and tetra-antennary n-glycan is a potential predictive biomarker for castration-resistant prostate cancer. Prostate 2014, 74, 1521-1529. [CrossRef]

75. Wang, D.; Dafik, L.; Nolley, R.; Huang, W.; Wolfinger, R.D.; Wang, L.X.; Peehl, D.M. Anti-oligomannose antibodies as potential serum biomarkers of aggressive prostate cancer. Drug Dev. Res. 2013, 74, 65-80. [CrossRef] [PubMed]

76. Kurimoto, A.; Kitazume, S.; Kizuka, Y.; Nakajima, K.; Oka, R.; Fujinawa, R.; Korekane, H.; Yamaguchi, Y.; Wada, Y.; Taniguchi, N. The absence of core fucose up-regulates gnt-iii and wnt target genes: A possible mechanism for an adaptive response in terms of glycan function. J. Biol. Chem. 2014, 289, 11704-11714. [CrossRef]

77. Wang, X.; Chen, J.; Li, Q.K.; Peskoe, S.B.; Zhang, B.; Choi, C.; Platz, E.A.; Zhang, H. Overexpression of alpha $(1,6)$ fucosyltransferase associated with aggressive prostate cancer. Glycobiology 2014, 24, 935-944. [CrossRef] [PubMed]

78. Hoti, N.; Yang, S.; Hu, Y.; Shah, P.; Haffner, M.C.; Zhang, H. Overexpression of alpha $(1,6)$ fucosyltransferase in the development of castration-resistant prostate cancer cells. Prostate Cancer Prostatic Dis. 2018, 21, 137-146. [CrossRef] [PubMed]

79. Fujita, K.; Hayashi, T.; Matsuzaki, K.; Nakata, W.; Masuda, M.; Kawashima, A.; Ujike, T.; Nagahara, A.; Tsuchiya, M.; Kobayashi, Y.; et al. Decreased fucosylated psa as a urinary marker for high gleason score prostate cancer. Oncotarget 2016, 7, 56643-56649. [CrossRef] [PubMed]

80. Zhou, J.; Yang, W.; Hu, Y.; Hoti, N.; Liu, Y.; Shah, P.; Sun, S.; Clark, D.; Thomas, S.; Zhang, H. Site-specific fucosylation analysis identifying glycoproteins associated with aggressive prostate cancer cell lines using tandem affinity enrichments of intact glycopeptides followed by mass spectrometry. Anal. Chem. 2017, 89, 7623-7630. [CrossRef] [PubMed]

81. Bond, M.R.; Hanover, J.A. A little sugar goes a long way: The cell biology of o-glcnac. J. Cell Biol. 2015, 208, 869-880. [CrossRef]

82. Hanover, J.A.; Krause, M.W.; Love, D.C. Bittersweet memories: Linking metabolism to epigenetics through o-glcnacylation. Nat. Rev. Mol. Cell Biol. 2012, 13, 312-321. [CrossRef] 
83. Fardini, Y.; Dehennaut, V.; Lefebvre, T.; Issad, T. O-glcnacylation: A new cancer hallmark? Front. Endocrinol. 2013, 4, 99. [CrossRef] [PubMed]

84. Hanover, J.A.; Chen, W.; Bond, M.R. O-glcnac in cancer: An oncometabolism-fueled vicious cycle. J. Bioenergy Biomembr. 2018, 50, 155-173. [CrossRef] [PubMed]

85. Aquino-Gil, M.; Pierce, A.; Perez-Cervera, Y.; Zenteno, E.; Lefebvre, T. Ogt: A short overview of an enzyme standing out from usual glycosyltransferases. Biochem. Soc. Trans. 2017, 45, 365-370. [CrossRef] [PubMed]

86. Chiaradonna, F.; Ricciardiello, F.; Palorini, R. The nutrient-sensing hexosamine biosynthetic pathway as the hub of cancer metabolic rewiring. Cells 2018, 7, 53. [CrossRef]

87. Itkonen, H.M.; Minner, S.; Guldvik, I.J.; Sandmann, M.J.; Tsourlakis, M.C.; Berge, V.; Svindland, A.; Schlomm, T.; Mills, I.G. O-glcnac transferase integrates metabolic pathways to regulate the stability of c-myc in human prostate cancer cells. Cancer Res. 2013, 73, 5277-5287. [CrossRef]

88. Itkonen, H.M.; Engedal, N.; Babaie, E.; Luhr, M.; Guldvik, I.J.; Minner, S.; Hohloch, J.; Tsourlakis, M.C.; Schlomm, T.; Mills, I.G. Uap1 is overexpressed in prostate cancer and is protective against inhibitors of n-linked glycosylation. Oncogene 2014, 34, 3744. [CrossRef] [PubMed]

89. Dennis, J.W.; Granovsky, M.; Warren, C.E. Glycoprotein glycosylation and cancer progression. Biochim. Biophys. Acta 1999, 1473, 21-34. [CrossRef]

90. Taniguchi, N.; Kizuka, Y. Glycans and cancer: Role of n-glycans in cancer biomarker, progression and metastasis, and therapeutics. Adv. Cancer Res. 2015, 126, 11-51.

91. Kawahara, R.; Ortega, F.; Rosa-Fernandes, L.; Guimaraes, V.; Quina, D.; Nahas, W.; Schwammle, V.; Srougi, M.; Leite, K.R.M.; Thaysen-Andersen, M.; et al. Distinct urinary glycoprotein signatures in prostate cancer patients. Oncotarget 2018, 9, 33077-33097. [CrossRef]

92. Bhat, G.; Hothpet, V.R.; Lin, M.F.; Cheng, P.W. Shifted golgi targeting of glycosyltransferases and alpha-mannosidase ia from giantin to gm130-grasp65 results in formation of high mannose n-glycans in aggressive prostate cancer cells. Biochim. Biophys. Acta. Gen. Subj. 2017, 1861, 2891-2901. [CrossRef]

93. Newsom-Davis, T.E.; Wang, D.; Steinman, L.; Chen, P.F.; Wang, L.X.; Simon, A.K.; Screaton, G.R. Enhanced immune recognition of cryptic glycan markers in human tumors. Cancer Res. 2009, 69, 2018-2025. [CrossRef]

94. Wang, D. N-glycan cryptic antigens as active immunological targets in prostate cancer patients. J. Proteom. Bioinform. 2012, 5, 090-095. [CrossRef] [PubMed]

95. Wang, D.; Herzenberg, L.; Peehl, D.; Herzenberg, L. Prostate Cancer Glycan Markers and Auto-Antibody Signatures. U.S. Patent No. 7,981,625, 19 July 2011.

96. Handerson, T.; Pawelek, J.M. Beta1,6-branched oligosaccharides and coarse vesicles: A common, pervasive phenotype in melanoma and other human cancers. Cancer Res. 2003, 63, 5363-5369.

97. Nonaka, M.; Fukuda, M.N.; Gao, C.; Li, Z.; Zhang, H.; Greene, M.I.; Peehl, D.M.; Feizi, T.; Fukuda, M. Determination of carbohydrate structure recognized by prostate-specific $\mathrm{f} 77$ monoclonal antibody through expression analysis of glycosyltransferase genes. J. Biol. Chem. 2014, 289, 16478-16486. [CrossRef]

98. Gao, D.; Vela, I.; Sboner, A.; Iaquinta, P.J.; Karthaus, W.R.; Gopalan, A.; Dowling, C.; Wanjala, J.N.; Undvall, E.A.; Arora, V.K.; et al. Organoid cultures derived from patients with advanced prostate cancer. Cell 2014, 159, 176-187. [CrossRef]

99. Zhang, G.; Zhang, H.; Wang, Q.; Lal, P.; Carroll, A.M.; de la Llera-Moya, M.; Xu, X.; Greene, M.I. Suppression of human prostate tumor growth by a unique prostate-specific monoclonal antibody $\mathrm{f77}$ targeting a glycolipid marker. Proc. Natl. Acad. Sci. USA 2010, 107, 732-737. [CrossRef]

100. Chen, X.; Nagai, Y.; Zhu, Z.; Ruan, H.; Peehl, D.M.; Greene, M.I.; Zhang, H. A spliced form of cd44 expresses the unique glycan that is recognized by the prostate cancer specific antibody f77. Oncotarget 2018, 9, 3631-3640. [CrossRef] [PubMed]

101. Daniotti, J.L.; Lardone, R.D.; Vilcaes, A.A. Dysregulated expression of glycolipids in tumor cells: From negative modulator of anti-tumor immunity to promising targets for developing therapeutic agents. Front. Oncol. 2015, 5, 300. [CrossRef] [PubMed]

102. Ravindranath, M.H.; Muthugounder, S.; Presser, N.; Selvan, S.R.; Portoukalian, J.; Brosman, S.; Morton, D.L. Gangliosides of organ-confined versus metastatic androgen-receptor-negative prostate cancer. Biochem. Biophys. Res. Commun. 2004, 324, 154-165. [CrossRef]

103. Hatano, K.; Miyamoto, Y.; Mori, M.; Nimura, K.; Nakai, Y.; Nonomura, N.; Kaneda, Y. Androgen-regulated transcriptional control of sialyltransferases in prostate cancer cells. PLoS ONE 2012, 7, e31234. [CrossRef] [PubMed] 
104. Iozzo, R.V.; Sanderson, R.D. Proteoglycans in cancer biology, tumour microenvironment and angiogenesis. J. Cell. Mol. Med. 2011, 15, 1013-1031. [CrossRef]

105. Edwards, I.J. Proteoglycans in prostate cancer. Nat. Rev. Urol. 2012, 9, 196-206. [CrossRef] [PubMed]

106. Ricciardelli, C.; Mayne, K.; Sykes, P.J.; Raymond, W.A.; McCaul, K.; Marshall, V.R.; Horsfall, D.J. Elevated levels of versican but not decorin predict disease progression in early-stage prostate cancer. Clin. Cancer Res. 1998, 4, 963-971.

107. Jacobsen, F.; Kraft, J.; Schroeder, C.; Hube-Magg, C.; Kluth, M.; Lang, D.S.; Simon, R.; Sauter, G.; Izbicki, J.R.; Clauditz, T.S.; et al. Up-regulation of biglycan is associated with poor prognosis and pten deletion in patients with prostate cancer. Neoplasia 2017, 19, 707-715. [CrossRef] [PubMed]

108. Sharpe, B.; Alghezi, D.A.; Cattermole, C.; Beresford, M.; Bowen, R.; Mitchard, J.; Chalmers, A.D. A subset of high gleason grade prostate carcinomas contain a large burden of prostate cancer syndecan-1 positive stromal cells. Prostate 2017, 77, 1312-1324. [CrossRef] [PubMed]

109. Szarvas, T.; Reis, H.; Vom Dorp, F.; Tschirdewahn, S.; Niedworok, C.; Nyirady, P.; Schmid, K.W.; Rubben, H.; Kovalszky, I. Soluble syndecan-1 (sdc1) serum level as an independent pre-operative predictor of cancer-specific survival in prostate cancer. Prostate 2016, 76, 977-985. [CrossRef]

110. Sakko, A.J.; Butler, M.S.; Byers, S.; Reinboth, B.J.; Stahl, J.; Kench, J.G.; Horvath, L.G.; Sutherland, R.L.; Stricker, P.D.; Henshall, S.M.; et al. Immunohistochemical level of unsulfated chondroitin disaccharides in the cancer stroma is an independent predictor of prostate cancer relapse. Cancer Epidemiol. Biomark. Prev. 2008, 17, 2488-2497. [CrossRef]

111. Sakko, A.J.; Ricciardelli, C.; Mayne, K.; Suwiwat, S.; LeBaron, R.G.; Marshall, V.R.; Tilley, W.D.; Horsfall, D.J. Modulation of prostate cancer cell attachment to matrix by versican. Cancer Res. 2003, 63, 4786-4791. [PubMed]

112. Ricciardelli, C.; Russell, D.L.; Ween, M.P.; Mayne, K.; Suwiwat, S.; Byers, S.; Marshall, V.R.; Tilley, W.D.; Horsfall, D.J. Formation of hyaluronan- and versican-rich pericellular matrix by prostate cancer cells promotes cell motility. J. Biol. Chem. 2007, 282, 10814-10825. [CrossRef]

113. Hu, Y.; Sun, H.; Owens, R.T.; Wu, J.; Chen, Y.Q.; Berquin, I.M.; Perry, D.; O’Flaherty, J.T.; Edwards, I.J. Decorin suppresses prostate tumor growth through inhibition of epidermal growth factor and androgen receptor pathways. Neoplasia 2009, 11, 1042-1053. [CrossRef] [PubMed]

114. Henke, A.; Grace, O.C.; Ashley, G.R.; Stewart, G.D.; Riddick, A.C.; Yeun, H.; O’Donnell, M.; Anderson, R.A.; Thomson, A.A. Stromal expression of decorin, semaphorin6d, sparc, sprouty1 and tsukushi in developing prostate and decreased levels of decorin in prostate cancer. PLOS ONE 2012, 7, e42516. [CrossRef]

115. Coulson-Thomas, V.J.; Coulson-Thomas, Y.M.; Gesteira, T.F.; Andrade de Paula, C.A.; Carneiro, C.R.; Ortiz, V.; Toma, L.; Kao, W.W.; Nader, H.B. Lumican expression, localization and antitumor activity in prostate cancer. Exp. Cell Res. 2013, 319, 967-981. [CrossRef]

116. Datta, M.W.; Hernandez, A.M.; Schlicht, M.J.; Kahler, A.J.; DeGueme, A.M.; Dhir, R.; Shah, R.B.; Farach-Carson, C.; Barrett, A.; Datta, S. Perlecan, a candidate gene for the capb locus, regulates prostate cancer cell growth via the sonic hedgehog pathway. Mol. Cancer 2006, 5, 9. [CrossRef]

117. Grindel, B.; Li, Q.; Arnold, R.; Petros, J.; Zayzafoon, M.; Muldoon, M.; Stave, J.; Chung, L.W.; Farach-Carson, M.C. Perlecan/hspg2 and matrilysin/mmp-7 as indices of tissue invasion: Tissue localization and circulating perlecan fragments in a cohort of 288 radical prostatectomy patients. Oncotarget 2016, 7, 10433-10447. [PubMed]

118. Fujii, T.; Shimada, K.; Tatsumi, Y.; Tanaka, N.; Fujimoto, K.; Konishi, N. Syndecan-1 up-regulates microrna-331-3p and mediates epithelial-to-mesenchymal transition in prostate cancer. Mol. Carcinog. 2015.

119. Shimada, K.; Anai, S.; Fujii, T.; Tanaka, N.; Fujimoto, K.; Konishi, N. Syndecan-1 (cd138) contributes to prostate cancer progression by stabilizing tumour-initiating cells. J. Pathol. 2013, 231, 495-504. [CrossRef] [PubMed]

120. Ebrahim, A.H.; Alalawi, Z.; Mirandola, L.; Rakhshanda, R.; Dahlbeck, S.; Nguyen, D.; Jenkins, M.; Grizzi, F.; Cobos, E.; Figueroa, J.A.; et al. Galectins in cancer: Carcinogenesis, diagnosis and therapy. Ann. Transl. Med. 2014, 2, 88. [PubMed]

121. Laderach, D.J.; Gentilini, L.D.; Giribaldi, L.; Delgado, V.C.; Nugnes, L.; Croci, D.O.; Al Nakouzi, N.; Sacca, P.; Casas, G.; Mazza, O.; et al. A unique galectin signature in human prostate cancer progression suggests galectin-1 as a key target for treatment of advanced disease. Cancer Res. 2013, 73, 86-96. [CrossRef] 
122. Nakajima, K.; Kho, D.H.; Yanagawa, T.; Harazono, Y.; Hogan, V.; Chen, W.; Ali-Fehmi, R.; Mehra, R.; Raz, A. Galectin-3 cleavage alters bone remodeling: Different outcomes in breast and prostate cancer skeletal metastasis. Cancer Res. 2016, 76, 1391-1402. [CrossRef]

123. Dondoo, T.O.; Fukumori, T.; Daizumoto, K.; Fukawa, T.; Kohzuki, M.; Kowada, M.; Kusuhara, Y.; Mori, H.; Nakatsuji, H.; Takahashi, M.; et al. Galectin-3 is implicated in tumor progression and resistance to anti-androgen drug through regulation of androgen receptor signaling in prostate cancer. Anticancer Res. 2017, 37, 125-134. [CrossRef]

124. Knapp, J.S.; Lokeshwar, S.D.; Vogel, U.; Hennenlotter, J.; Schwentner, C.; Kramer, M.W.; Stenzl, A.; Merseburger, A.S. Galectin-3 expression in prostate cancer and benign prostate tissues: Correlation with biochemical recurrence. World J. Urol. 2013, 31, 351-358. [CrossRef]

125. Payton, S. Prostate cancer: 'Galectin signature' reveals gal-1 as key player in angiogenesis. Nat. Rev. Urol. 2012, 9, 667. [CrossRef]

126. Shih, T.C.; Liu, R.; Wu, C.T.; Li, X.; Xiao, W.; Deng, X.; Kiss, S.; Wang, T.; Chen, X.J.; Carney, R.; et al. Targeting galectin-1 impairs castration-resistant prostate cancer progression and invasion. Clin. Cancer Res. 2018, 24, 4319-4331. [CrossRef]

127. Wang, Y.; Nangia-Makker, P.; Tait, L.; Balan, V.; Hogan, V.; Pienta, K.J.; Raz, A. Regulation of prostate cancer progression by galectin-3. Am. J. Pathol. 2009, 174, 1515-1523. [CrossRef] [PubMed]

128. Tsai, C.H.; Tzeng, S.F.; Chao, T.K.; Tsai, C.Y.; Yang, Y.C.; Lee, M.T.; Hwang, J.J.; Chou, Y.C.; Tsai, M.H.; Cha, T.L.; et al. Metastatic progression of prostate cancer is mediated by autonomous binding of galectin-4-o-glycan to cancer cells. Cancer Res. 2016, 76, 5756-5767. [CrossRef] [PubMed]

129. Tzeng, S.F.; Tsai, C.H.; Chao, T.K.; Chou, Y.C.; Yang, Y.C.; Tsai, M.H.; Cha, T.L.; Hsiao, P.W. O-glycosylation-mediated signaling circuit drives metastatic castration-resistant prostate cancer. FASEB J. 2018, 32, 6869-6882. [CrossRef]

130. Gentilini, L.D.; Jaworski, F.M.; Tiraboschi, C.; Perez, I.G.; Kotler, M.L.; Chauchereau, A.; Laderach, D.J.; Compagno, D. Stable and high expression of galectin- 8 tightly controls metastatic progression of prostate cancer. Oncotarget 2017, 8, 44654-44668. [CrossRef] [PubMed]

131. Munkley, J. Glycosylation is a global target for androgen control in prostate cancer cells. Endocr. Relat. Cancer 2017, 24, R49-R64. [CrossRef]

132. Munkley, J.; Vodak, D.; Livermore, K.E.; James, K.; Wilson, B.T.; Knight, B.; McCullagh, P.; McGrath, J.; Crundwell, M.; Harries, L.W.; et al. Glycosylation is an androgen-regulated process essential for prostate cancer cell viability. EBioMedicine 2016, 8, 103-116. [CrossRef]

133. Sato, T.; Yoneyama, T.; Tobisawa, Y.; Hatakeyama, S.; Yamamoto, H.; Kojima, Y.; Mikami, J.; Mori, K.; Hashimoto, Y.; Koie, T.; et al. Core 2 beta-1, 6-n-acetylglucosaminyltransferase-1 expression in prostate biopsy specimen is an indicator of prostate cancer aggressiveness. Biochem. Biophys. Res. Commun. 2016, 470, 150-156. [CrossRef]

134. Hagisawa, S.; Ohyama, C.; Takahashi, T.; Endoh, M.; Moriya, T.; Nakayama, J.; Arai, Y.; Fukuda, M. Expression of core 2 beta1,6-n-acetylglucosaminyltransferase facilitates prostate cancer progression. Glycobiology 2005, 15, 1016-1024. [CrossRef] [PubMed]

135. Wei, A.; Fan, B.; Zhao, Y.; Zhang, H.; Wang, L.; Yu, X.; Yuan, Q.; Yang, D.; Wang, S. St6gal-i overexpression facilitates prostate cancer progression via the pi3k/akt/gsk-3beta/beta-catenin signaling pathway. Oncotarget 2016, 7, 65374-65388. [CrossRef] [PubMed]

136. Li, J.; Guillebon, A.D.; Hsu, J.W.; Barthel, S.R.; Dimitroff, C.J.; Lee, Y.F.; King, M.R. Human fucosyltransferase 6 enables prostate cancer metastasis to bone. Br. J. Cancer 2013, 109, 3014-3022. [CrossRef]

137. Livermore, K.E.; Munkley, J.; Elliott, D.J. Androgen receptor and prostate cancer. AIMS Mol. Sci. 2016, 3, 280-299. [CrossRef]

138. Sharp, A.; Coleman, I.; Yuan, W.; Sprenger, C.; Dolling, D.; Rodrigues, D.N.; Russo, J.W.; Figueiredo, I.; Bertan, C.; Seed, G.; et al. Androgen receptor splice variant-7 expression emerges with castration resistance in prostate cancer. J. Clin. Investig. 2019, 129, 192-208. [CrossRef] [PubMed]

139. Kojima, Y.; Yoneyama, T.; Hatakeyama, S.; Mikami, J.; Sato, T.; Mori, K.; Hashimoto, Y.; Koie, T.; Ohyama, C.; Fukuda, M.; et al. Detection of core2 beta-1,6-n-acetylglucosaminyltransferase in post-digital rectal examination urine is a reliable indicator for extracapsular extension of prostate cancer. PLoS ONE 2015, 10, e0138520. [CrossRef] 
140. Albitar, M.; Ma, W.; Lund, L.; Albitar, F.; Diep, K.; Fritsche, H.A.; Shore, N. Predicting prostate biopsy results using a panel of plasma and urine biomarkers combined in a scoring system. J. Cancer 2016, 7, 297-303. [CrossRef]

141. Ma, W.; Diep, K.; Fritsche, H.A.; Shore, N.; Albitar, M. Diagnostic and prognostic scoring system for prostate cancer using urine and plasma biomarkers. Genet. Test. Mol. Biomark. 2014, 18, 156-163. [CrossRef]

142. Knuuttila, M.; Mehmood, A.; Huhtaniemi, R.; Yatkin, E.; Hakkinen, M.R.; Oksala, R.; Laajala, T.D.; Ryberg, H.; Handelsman, D.J.; Aittokallio, T.; et al. Antiandrogens reduce intratumoral androgen concentrations and induce androgen receptor expression in castration-resistant prostate cancer xenografts. Am. J. Pathol. 2018, 188, 216-228. [CrossRef]

143. Mikami, J.; Tobisawa, Y.; Yoneyama, T.; Hatakeyama, S.; Mori, K.; Hashimoto, Y.; Koie, T.; Ohyama, C.; Fukuda, M. I-branching n-acetylglucosaminyltransferase regulates prostate cancer invasiveness by enhancing alpha5beta1 integrin signaling. Cancer Sci. 2016, 107, 359-368. [CrossRef] [PubMed]

144. Barfeld, S.J.; East, P.; Zuber, V.; Mills, I.G. Meta-analysis of prostate cancer gene expression data identifies a novel discriminatory signature enriched for glycosylating enzymes. BMC Med. Genom. 2014, 7, 513. [CrossRef]

145. Tsui, K.H.; Chang, P.L.; Feng, T.H.; Chung, L.C.; Sung, H.C.; Juang, H.H. Evaluating the function of matriptase and n-acetylglucosaminyltransferase v in prostate cancer metastasis. Anticancer Res. 2008, 28, 1993-1999. [PubMed]

146. Soung, Y.H.; Ford, S.; Zhang, V.; Chung, J. Exosomes in cancer diagnostics. Cancers 2017, 9, 8. [CrossRef] [PubMed]

147. Drake, R.R.; Kislinger, T. The proteomics of prostate cancer exosomes. Expert Rev. Proteom. 2014, 11, 167-177. [CrossRef] [PubMed]

148. Williams, C.; Royo, F.; Aizpurua-Olaizola, O.; Pazos, R.; Boons, G.J.; Reichardt, N.C.; Falcon-Perez, J.M. Glycosylation of extracellular vesicles: Current knowledge, tools and clinical perspectives. J. Extracell. Vesicles 2018, 7, 1442985. [CrossRef] [PubMed]

149. Vlaeminck-Guillem, V. Extracellular vesicles in prostate cancer carcinogenesis, diagnosis, and management. Front. Oncol. 2018, 8, 222. [CrossRef] [PubMed]

150. Gerlach, J.Q.; Griffin, M.D. Getting to know the extracellular vesicle glycome. Mol. Biosyst. 2016, 12, 1071-1081. [CrossRef] [PubMed]

151. Nyalwidhe, J.O.; Betesh, L.R.; Powers, T.W.; Jones, E.E.; White, K.Y.; Burch, T.C.; Brooks, J.; Watson, M.T.; Lance, R.S.; Troyer, D.A.; et al. Increased bisecting n-acetylglucosamine and decreased branched chain glycans of n-linked glycoproteins in expressed prostatic secretions associated with prostate cancer progression. Proteom. Clin. Appl. 2013, 7, 677-689.

152. Lopez Aguilar, A.; Meng, L.; Hou, X.; Li, W.; Moremen, K.W.; Wu, P. Sialyltransferase-based chemoenzymatic histology for the detection of n- and o-glycans. Bioconjugate Chem. 2018, 29, 1231-1239. [CrossRef]

153. Powers, T.W.; Neely, B.A.; Shao, Y.; Tang, H.; Troyer, D.A.; Mehta, A.S.; Haab, B.B.; Drake, R.R. Maldi imaging mass spectrometry profiling of n-glycans in formalin-fixed paraffin embedded clinical tissue blocks and tissue microarrays. PLoS ONE 2014, 9, e106255. [CrossRef]

154. Lemaire, R.; Desmons, A.; Tabet, J.C.; Day, R.; Salzet, M.; Fournier, I. Direct analysis and maldi imaging of formalin-fixed, paraffin-embedded tissue sections. J. Proteome Res. 2007, 6, 1295-1305. [CrossRef]

155. Drake, R.R.; West, C.A.; Mehta, A.S.; Angel, P.M. Maldi mass spectrometry imaging of n-linked glycans in tissues. Adv. Exp. Med. Biol. 2018, 1104, 59-76.

156. Gerlinger, M.; Rowan, A.J.; Horswell, S.; Math, M.; Larkin, J.; Endesfelder, D.; Gronroos, E.; Martinez, P.; Matthews, N.; Stewart, A.; et al. Intratumor heterogeneity and branched evolution revealed by multiregion sequencing. N. Engl. J. Med. 2012, 366, 883-892. [CrossRef]

157. Vandekerkhove, G.; Chi, K.N.; Wyatt, A.W. Clinical utility of emerging liquid biomarkers in advanced prostate cancer. Cancer Genet. 2018, 228-229, 151-158. [CrossRef]

158. Riaz, I.B.; Wang, L.; Kohli, M. Liquid biopsy approach in the management of prostate cancer. Transl. Res. 2018, 201, 60-70. [CrossRef]

159. Gomella, L.G. The liquid biopsy for prostate cancer 25 years later. Can. J. Urol. 2017, 24, 8693-8694.

160. Morrison, G.J.; Goldkorn, A. Development and application of liquid biopsies in metastatic prostate cancer. Curr. Oncol. Rep. 2018, 20, 35. [CrossRef] 
161. Fletcher, C. Ar-v7 liquid biopsy for treatment stratification in prostate cancer: How close are we? Curr. Opin. Urol. 2017, 27, 500-509. [CrossRef] [PubMed]

162. Valentino, A.; Reclusa, P.; Sirera, R.; Giallombardo, M.; Camps, C.; Pauwels, P.; Crispi, S.; Rolfo, C. Exosomal micrornas in liquid biopsies: Future biomarkers for prostate cancer. Clin. Transl. Oncol. 2017, 19, 651-657. [CrossRef] [PubMed]

163. Chen, Z.H.; Zhang, G.L.; Li, H.R.; Luo, J.D.; Li, Z.X.; Chen, G.M.; Yang, J. A panel of five circulating micrornas as potential biomarkers for prostate cancer. Prostate 2012, 72, 1443-1452. [CrossRef] [PubMed]

164. Haldrup, C.; Kosaka, N.; Ochiya, T.; Borre, M.; Hoyer, S.; Orntoft, T.F.; Sorensen, K.D. Profiling of circulating micrornas for prostate cancer biomarker discovery. Drug Deliv. Transl. Res. 2014, 4, 19-30. [CrossRef] [PubMed]

165. Groskopf, J.; Aubin, S.M.; Deras, I.L.; Blase, A.; Bodrug, S.; Clark, C.; Brentano, S.; Mathis, J.; Pham, J.; Meyer, T.; et al. Aptima pca3 molecular urine test: Development of a method to aid in the diagnosis of prostate cancer. Clin. Chem. 2006, 52, 1089-1095. [CrossRef]

166. Salami, S.S.; Schmidt, F.; Laxman, B.; Regan, M.M.; Rickman, D.S.; Scherr, D.; Bueti, G.; Siddiqui, J.; Tomlins, S.A.; Wei, J.T.; et al. Combining urinary detection of tmprss2:Erg and pca3 with serum psa to predict diagnosis of prostate cancer. Urol. Oncol. 2013, 31, 566-571. [CrossRef]

167. Tomlins, S.A.; Aubin, S.M.; Siddiqui, J.; Lonigro, R.J.; Sefton-Miller, L.; Miick, S.; Williamsen, S.; Hodge, P.; Meinke, J.; Blase, A.; et al. Urine tmprss2:Erg fusion transcript stratifies prostate cancer risk in men with elevated serum psa. Sci. Transl. Med. 2011, 3, 94ra72. [CrossRef]

168. Wu, T.; Giovannucci, E.; Welge, J.; Mallick, P.; Tang, W.Y.; Ho, S.M. Measurement of gstp1 promoter methylation in body fluids may complement psa screening: A meta-analysis. Br. J. Cancer 2011, 105, 65-73. [CrossRef]

169. He, W.S.; Bishop, K.S. The potential use of cell-free-circulating-tumor DNA as a biomarker for prostate cancer. Expert Rev. Mol. Diagn. 2016, 16, 839-852. [CrossRef] [PubMed]

170. Pan, J.; Ding, M.; Xu, K.; Yang, C.; Mao, L.J. Exosomes in diagnosis and therapy of prostate cancer. Oncotarget 2017, 8, 97693-97700. [CrossRef]

171. Sumanasuriya, S.; Omlin, A.G.; Armstrong, A.J.; Attard, G.; Chi, K.N.; Bevan, C.L.; Waugh, D.J.; Ijzerman, M.J.; De Laere, B.; Lolkema, M.P.; et al. Consensus statement on circulating biomarkers for advanced prostate cancer. Eur. Urol. Oncol. 2018, 1, 151-159. [CrossRef]

172. Castro-Giner, F.; Gkountela, S.; Donato, C.; Alborelli, I.; Quagliata, L.; Ng, C.K.Y.; Piscuoglio, S.; Aceto, N. Cancer diagnosis using a liquid biopsy: Challenges and expectations. Diagnostics 2018, 8, 31. [CrossRef]

173. Ko, J.; Baldassano, S.N.; Loh, P.L.; Kording, K.; Litt, B.; Issadore, D. Machine learning to detect signatures of disease in liquid biopsies-A user's guide. Lab Chip 2018, 18, 395-405. [CrossRef] [PubMed]

174. Dalziel, M.; Crispin, M.; Scanlan, C.N.; Zitzmann, N.; Dwek, R.A. Emerging principles for the therapeutic exploitation of glycosylation. Science 2014, 343, 1235681. [CrossRef] [PubMed]

175. Salanti, A.; Clausen, T.M.; Agerbaek, M.O.; Al Nakouzi, N.; Dahlback, M.; Oo, H.Z.; Lee, S.; Gustavsson, T.; Rich, J.R.; Hedberg, B.J.; et al. Targeting human cancer by a glycosaminoglycan binding malaria protein. Cancer Cell 2015, 28, 500-514. [CrossRef] [PubMed]

176. Ernst, B.; Magnani, J.L. From carbohydrate leads to glycomimetic drugs. Nat. Rev. Drug Discov. 2009, 8, 661-677. [CrossRef] [PubMed]

177. Hudak, J.E.; Bertozzi, C.R. Glycotherapy: New advances inspire a reemergence of glycans in medicine. Chem. Biol. 2014, 21, 16-37. [CrossRef] [PubMed]

178. Salatino, M.; Girotti, M.R.; Rabinovich, G.A. Glycans pave the way for immunotherapy in triple-negative breast cancer. Cancer Cell 2018, 33, 155-157. [CrossRef]

179. Bull, C.; Boltje, T.J.; van Dinther, E.A.; Peters, T.; de Graaf, A.M.; Leusen, J.H.; Kreutz, M.; Figdor, C.G.; den Brok, M.H.; Adema, G.J. Targeted delivery of a sialic acid-blocking glycomimetic to cancer cells inhibits metastatic spread. ACS Nano 2015, 9, 733-745. [CrossRef]

(C) 2019 by the authors. Licensee MDPI, Basel, Switzerland. This article is an open access article distributed under the terms and conditions of the Creative Commons Attribution (CC BY) license (http:/ / creativecommons.org/licenses/by/4.0/). 